\title{
PENGARUH EFEKTIVITAS PENGENDALIAN INTERNAL, KESESUAIAN KOMPENSASI, ASIMETRI INFORMASI, DAN MORALITAS MANAJEMEN TERHADAP PERILAKU TIDAK ETIS DAN KECENDERUNGAN KECURANGAN AKUNTANSI (Studi Pada Perusahaan Perbankan Di Kota Bengkulu)
}

\author{
Mirra Sri Wahyuni ${ }^{1}$, Helmarini ${ }^{2}$ \\ ${ }^{1 \& 2}$ Universitas Muhammadiyah Bengkulu \\ Mirrasriwahyuni91@gmail.com ${ }^{1}, \underline{\text { helmarini0303@gmail.com }}^{2}$
}

\begin{abstract}
The study aims to determine the effect of effectiveness of internal control, compensation compatibility, information asymmetry, and morality of management to unethical behavior and tendency of fraud accounting (study on banking companies in Bengkulu city). The data used in this research is primary data, obtained by distributing questionnaires to the respondents. Total sampel used for this study are 50 sampels. The data was analyzed by using SmartPLS 2.0 M3. The results prove that effectiveness of internal control, compensation compatibility, and morality of management have negative effect on unethical behavior. Effectiveness of internal control, compensation compatibility, and morality of management have negative effect on tendency of fraud accounting, but information asymmetry has no effect on unethical behavior and tendency of fraud accounting. Unethical behavior has positive effect on tendency of fraud accounting.

Keywords: Effectiveness of Internal Control, Compensation Compatibility, Information Asymmetry, Morality of Management, Unethical Behavior, Tendency of Fraud Accounting
\end{abstract}

\section{PENDAHULUAN}

Dalam dunia bisnis seringkali terjadi kecurangan-kecurangan atau tindakan yang menyimpang dari prosedur akuntansi yang benar, dimana kecurangan tersebut disebut kecurangan akuntansi. Contoh dari kasus kecurangan pada industri perbankan di Indonesia adalah skandal penerbitan laporan keuangan ganda Bank Lippo pada tahun 2002, dimana terdapat perbedaan dari kedua laporan keuangan tersebut yang diduga terjadi karena adanya manipulasi yang dilakukan manajemen (Sumantyo, 2003) dan kasus yang melibatkan Bank Century dimana manajemen bank tersebut melakukan rekayasa akuntansi agar rasio kecukupan modal bank memenuhi syarat rasio yang telah ditetapkan Bank Indonesia (Prasetyo, 2009). Kecenderungan kecurangan akuntansi dapat disebabkan oleh faktor-faktor tertentu, dan kecenderungan kecurangan akuntansi ini dapat dijelaskan menggunakan teori atribusi. Teori atribusi yang dikemukakan oleh Fritz Heider menjelaskan tentang penyebab seseorang melakukan perilaku tertentu (Luthans, 2005). Teori atribusi ini selain dapat digunakan untuk menjelaskan faktor-faktor yang mempengaruhi kecenderungan kecurangan akuntansi juga berlaku untuk perilaku tidak etis, jadi seseorang melakukan hal tersebut didasarkan oleh atribut penyebab atau 
disebabkan oleh faktor-faktor tertentu. Dengan diketahui faktor-faktor tersebut, dapat dilakukan pencegahan untuk hal tersebut. Faktor-faktor yang mempengaruhi kecenderungan akuntansi dan perilaku tidak etis tersebut telah diteliti oleh beberapa peneliti dahulu seperti efektivitas pengendalian internal, kesesuaian kompensasi, asimetri informasi, dan moralitas manajemen.

Kecenderungan kecurangan akuntansi yang dilakukan oleh manajemen perusahaan dapat dipengaruhi oleh perilaku tidak etis dari manajemen tersebut. Sumber daya manusia yang menjalankan perusahaan atau manajemen perusahaan merupakan salah satu sumber daya yang sangat penting bagi perusahaan, manajemen yang diharapkan adalah manajemen yang handal, terlatih, dan jujur dan berperilaku etis, tetapi dalam kenyataannya tidak semua karyawan atau manajemen perusahaan tersebut demikian, terdapat beberapa atau mungkin sebagian dari manajemen tersebut berperilaku tidak etis.

Menurut Fauwzi (2011) tindakan tidak etis dapat dipengaruhi oleh adanya sistem pengendalian internal dan monitoring oleh atasan. Untuk mendapatkan hasil monitoring yang baik, diperlukan pengendalian internal perusahaan yang efektif (Wilopo, 2006). Pengendalian internal yang efektif akan menutup peluang terjadinya perilaku yang tidak etis. Cara lain yang dilakukan perusahaan untuk menghindari kerugian akibat ulah karyawan yang berperilaku tidak etis adalah dengan mengetahui bagaimana moral pada tiap karyawan. Hal ini bertujuan untuk memberi pengarahan atau sosialisasi agar karyawan memiliki moralitas yang tinggi pada perusahaan. Moral adalah istilah manusia menyebut ke manusia atau orang lainnya dalam tindakan yang memiliki nilai positif, sedangkan manusia yang tidak memiliki moral disebut amoral yang artinya dia tidak bermoral dan tidak memiliki nilai positif di mata manusia lainya (Rahmawati dan Soetik, 2012). Nicholson (1997) mencatat bahwa perilaku tidak etis yang dilakukan oleh manajemen juga dapat dipengaruhi oleh situasi asimetri informasi. Asimetri informasi disebabkan oleh permasalahan keagenan yang terjadi bila prinsipal merasa kesulitan untuk menelusuri apa yang sebenarnya dilakukan oleh agen. Menurut Prayogo (2009), adanya asimetri informasi antara manajer sebagai (agent) dan pemilik (principal) menyebabkan kesenjangan pengetahuan keuangan internal perusahaan, sehingga pihak manajer bisa melakukan rekayasa demi meningkatkan laba untuk mendapat kompensasi atau imbalan dari pemilik. Dengan semakin berkurangnya asimetri informasi antara manajemen (agen) dan pemegang saham (prinsipal), perilaku tidak etis dapat dikurangi. Selain faktorfaktor tersebut, kesesuaian kompensasi juga merupakan salah satu faktor yang mempengaruhi perilaku tidak etis. Randa dan Meliana (2009) mendefinisikan kompensasi sebagai balas jasa yang diberikan oleh perusahaan kepada manajer, yang dapat bersifat finansial maupun non finansial, pada periode yang tetap. Dengan adanya kesesuaian kompensasi, perilaku tidak etis yang dilakukan karyawan akan berkurang.

Kecenderungan kecurangan akuntansi selain dipengaruhi oleh perilaku tidaketis, juga dapat dipengaruhi langsung oleh faktor keefektifan pengendalian internal, 
kesesuaian kompensasi, asimetri informasi, dan moralitas manajemen. Kecenderungan kecurangan akuntansi dipengaruhi oleh ada atau tidaknya peluang untuk melakukan hal tersebut (Fauwzi, 2011). Peluang tersebut dapat diminimalisir dengan adanya pengendalian internal yang efektif. Smith et al., (1997) menyatakan bahwa pengendalian internal yang efektif akan mengurangi kecenderungan kecurangan akuntansi. Selain dipengaruhi keefektifan pengendalian internal, kecenderungan kecurangan akuntansi juga dipengaruhi oleh kompensasi yang diterima karyawan. Jensen and Meckling (1976) menjelaskan dalam teori keagenan bahwa pemberian kompensasi yang memadai membuat agen (manajemen) bertindak sesuai dengan keinginan dari prinsipal (pemegang saham), yaitu memberikan informasi yang sebenarnya tentang keadaan perusahaan. Manajemen akan beritndak sesuai dengan keinginan prinsipal (pemegang saham) jika mereka mendapatkan kompensasi yang sesuai dengan kinerjanya. Pemberian kompensasi ini dapat mengurangi kecenderungan kecurangan akuntansi.

Penelitian ini mengacu pada penelitian Randa dan Meliana (2009), Rahmawati (2012), Yuli (2013), Hadi dan Prasaja (2015), dan Bellyanti dan Rasmini (2016), pada penelitian ini variabel penelitian menggunakan gabungan dari kelima penelitian tersebut sehingga pada penelitian ini variabel yang digunakan lebih banyak dan hipotesis yang diajukan juga lebih banyak. Penggunaan variabel gabungan dari kelima penelitian tersebut juga dikarenakan hasil dari kelima penelitian tersebut tidak cukup konsisten, karena terdapat beberapa perbedaaan hasil penelitian, sehingga hasil penelitian ini diharapkan dapat memberikan hasil yang mendukung atau mungkin bisa memberikan hasil yang berbeda sehingga dapat mengembangkan penelitian sejenis ke depannya.

Alasan objek penelitian ini pada industri perbankan karena industri perbankan saat ini dalam penerapan teknologinya sudah sangat canggih, pengendalian internalnya juga semakin ketat, hal ini sebagai dampak dari munculnya kasus-kasus terdahulu yang melibatkan kecurangan akuntansi dan perilaku tidak etis di industri perbankan. Oleh sebab itu, di masa di mana semuanya sudah semakin terbuka, industri perbankan dituntut untuk semakin baik dalam tata kelola perusahaan yang baik dan benar (good corporate governance) yang dilaporkan dalam laporan GCG perusahaan. Oleh sebab itu, melakukan penelitian di industri perbankan ini menjadi menarik, karena untuk membuktikan sudah sebaik dan sejauh mana industri perbankan khususnya di kota Bengkulu sudah mengantisipasi mengenai kecenderungan kecurangan akuntansi dan perilaku tidak etis di bank tersebut. Alasan pemilihan subjek penelitian adalah karyawan bank bagian akuntansi dan keuangan karena mereka merupakan pihak-pihak yang lebih paham mengenai seluruh kegiatan keuangan bank dan mereka juga terlibat dalam kegiatan keuangan atau akuntansi di bank tersebut.

Berdasarkan uraian di atas, maka permasalahan pokok dalam penelitian ini adalah: (1) apakah efektifivitas pengendalian internal berpengaruh negatif terhadap perilaku tidak etis. (2) apakah efektifivitas pengendalian internal berpengaruh negatif 
terhadap kecenderungan kecurangan akuntansi. (3) apakah kesesuaian kompensasi berpengaruh negatif terhadap perilaku tidak etis (4) pakah kesesuaian kompensasi berpengaruh negatif terhadap kecenderungan kecurangan akuntansi. (5) apakah asimetri informasi berpengaruh positif terhadap perilaku tidak etis. (6) apakah asimetri informasi berpengaruh positif terhadap kecenderungan kecurangan akuntansi. (7) apakah moralitas manajemen berpengaruh negatif terhadap perilaku tidak etis. (8) apakah moralitas manajemen berpengaruh negatif terhadap kecenderungan kecurangan akuntansi. (9) apakah perilaku tidak etis berpengaruh positif terhadap kecenderungan kecurangan akuntansi.

\section{TINJAUAN PUSTAKA}

\section{Teori Atribusi}

Teori Atribusi dikembangkan oleh Fritz Heider yang yang menjelaskan teori tentang penyebab seseorang melakukan perilaku tertentu. Apakah perilaku itu disebabkan oleh faktor disposisional (faktor internal/dalam), misalnya sifat, karakter, sikap, dan lain sebagainya, atau disebabkan oleh keadaan eksternal, misalnya tekanan situasi atau keadaan tertentu yang memaksa seseorang melakukan perbuatan tertentu (Luthans, 2005). Dengan adanya sistem pengendalian yang efektif diharapkan dapat mengurangi adanya perilaku tidak etis dan kecurangan akuntansi. Kompensasi yang diterima oleh karyawan perusahaan juga dapat menjadi penyebab karyawan tersebut berperilaku tidak etis dan melakukan kecurangan akuntansi, karena kompensasi yang tidak memadai atau tidak sesuai kebutuhan karyawan akan membuat karyawan tersebut melakukan hal-hal yang tidak etis dan curang untuk memenuhi kebutuhan hidupnya. Moralitas yang dimiliki karyawan juga dapat mempengaruhi setiap tindakan karyawan tersebut, karyawan yang memang memiliki moralitas rendah walaupun digaji dengan baik masih mungkin untuk melakukan perilaku tidak etis dan malakukan kecurangan akuntansi demi kepentingan dirinya.

\section{Efektivitas Pengendalian Internal dan Perilaku Tidak Etis}

Teori atribusi yang dikemukakan oleh Fritz Heider menjelaskan tentang penyebab seseorang melakukan perilaku tertentu. Teori atribusi ini juga berlaku untuk perilaku tidak etis, jadi seseorang melakukan hal tersebut didasarkan oleh atribut penyebab atau disebabkan oleh faktor-faktor tertentu. Dengan diketahui faktorfaktor tersebut, dapat dilakukan pencegahan untuk hal tersebut. Efektivitas pengendalian internal merupakan suatu hal yang mempengaruhi tindakan dan perilaku seseorang. Dengan adanya pengendalian internal yang efektif maka tindakan tidak etis akan berkurang. Jika keefektifan pengendalian internal tinggi maka perilaku tidak etis akan menurun. Mengantisipasi adanya tindakan menyimpang yang dapat dilakukan oleh pihak manajemen maka pemilik perusahaan harus melakukan pengawasan terhadap kinerja manajemen dengan sistem pengendalian yang efektif. Sistem pengendalian tersebut diharapkan mampu mengurangi adanya perilaku menyimpang (perilaku tidak etis). Dengan adanya pengendalian internal maka tindakan tidak etis akan berkurang. Jika keefektifan pengendalian internal tinggi maka perilaku tidak etis akan menurun. Menurut Griffin dan Ebert (2006) perilaku etis adalah perilaku yang sesuai 
dengan norma-norma sosial yang diterima secara umum sehubungan dengan tindakan-tindakan yang benar dan baik. Jadi perilaku tidak etis adalah perilaku yang tidak sesuai dengan norma-norma sosial yang diterima secara umum sehubungan dengan tindakan-tindakan yang benar dan baik. Penelitian Wilopo (2006), Thoyibatun (2009), Fauwzi (2009), Yuli (2013), dan Bellyanti dan Rasmini (2016) menunjukkan bahwa efektivitas pengendalian internal berpengaruh negatif terhadap perilaku tidak etis. Oleh karena itu, diajukan hipotesis sebagai berikut:

H1: Efektivitas pengendalian internal berpengaruh negatif terhadap perilaku tidak etis.

\section{Efektivitas Pengendalian Internal dan Kecenderungan Kecurangan Akuntansi}

Teori atribusi menjelaskan bahwa tindakan seorang pemimpin maupun orang yang diberikan wewenang dipengaruhi oleh atribut penyebab (Green and Mitchell, dalam Waworuntu, 2003). Dengan adanya pengendalian internal yang efektif maka akan mengurangi terjadinya tindakan kecurangan akuntansi. Kecenderungan kecurangan akuntansi dipengaruhi oleh ada atau tidaknya peluang untuk melakukan hal tersebut (Glifandi, 2011). Peluang tersebut dapat diminimalisir dengan adanya pengendalian internal yang efektif. Smith et al. (1997) menyatakan bahwa pengendalian internal yang efektif akan mengurangi kecenderungan kecurangan akuntansi. AICPA menjelaskan bahwa pengendalian internal sangat penting, antara lain untuk memberikan perlindungan bagi entitas terhadap kelemahan manusia serta untuk mengurangi kemungkinan kesalahan dan tindakan yang tidak sesuai dengan aturan (Wilopo, 2006). COSO menjelaskan bahwa semakin berkembangnya suatu perusahaan, maka tugas manajemen untuk mengendalikan jalannya perusahaan menjadi semakin berat. Agar tujuan yang telah ditetapkan dapat dicapai, keamanan harta perusahaan terjamin dan kegiatan operasi bisa dijalankan secara efektif dan efisien, maka perlu diadakan struktur pengendalian internal yang baik dan efektif untuk mencegah terjadinya kecurangan akuntansi (Wilopo, 2006) Penelitian Wilopo (2006), Thoyibatun (2009), Fauwzi (2009), Randa dan Meliana (2009), dan Rahmawati (2012) menunjukkan bahwa efektivitas pengendalian internal berpengaruh negatif terhadap kecenderungan kecurangan akuntansi. Oleh karena itu, diajukan hipotesis sebagai berikut:

H2: Efektivitas pengendalian internal berpengaruh negatif terhadap kecenderungan kecurangan akuntansi.

\section{Kesesuaian Kompensasi dan Perilaku Tidak Etis}

Dalam teori atribusi, tindakan seorang pemimpin maupun orang yang diberikan wewenang dipengaruhi oleh atribut penyebab (Green and Mitchell, 1979, dalam Waworuntu, 2003). Hasibuan (2009) menjelaskan kompensasi adalah semua pendapatan yang berbentuk uang maupun barang langsung atau tidak langsung yang diterima karyawan sebagai imbalan atas jasa yang diberikan kepada perusahaan. Kompensasi merupakan hal yang berpengaruh terhadap tindakan maupun perilaku seseorang dalam organisasi. Seseorang cenderung berperilaku tidak etis untuk memaksimalkan keuntungan pribadinya. Kompensasi tersebut bertujuan agar manajemen dapat bertindak sesuai keinginan pemilik perusahaan dan tidak 
melakukan tindakan menyimpang seperti adanya perilaku tidak etis. Tindakan menyimpang diharapkan dapat berkurang dengan adanya sistem kompensasi yang diberikan. Menurut Griffin dan Ebert (2006) perilaku etis adalah perilaku yang sesuai dengan norma-norma sosial yang diterima secara umum sehubungan dengan tindakan-tindakan yang benar dan baik. Jadi perilaku tidak etis adalah perilaku yang tidak sesuai dengan norma-norma sosial yang diterima secara umum sehubungan dengan tindakan-tindakan yang benar dan baik. Kompensasi yang sesuai menjadi bagian yang sangat penting bagi kinerja karyawan serta keberhasilan organisasi (Luthans, 2005). Pendapat ini didukung oleh Wright (2003) dalam Wilopo (2006) yang menyatakan bahwa insentif, pengawasan serta sistem yang berjalan dengan baik dapat mencegah perilaku tidak etis manajemen perusahaan. Penelitian Thoyibatun (2009) dan Yuli (2013) menunjukkan bahwa kesesuaian kompensasi berpengaruh negatif terhadap perilaku tidak etis. Oleh karena itu, diajukan hipotesis sebagai berikut:

H3: Kesesuaian kompensasi berpengaruh negatif terhadap perilaku tidak etis

\section{Kesesuaian Kompensasi dan Kecenderungan Kecurangan Akuntansi}

Dalam teori atribusi, tindakan seorang pemimpin maupun orang yang diberikan wewenang dipengaruhi oleh atribut penyebab (Green and Mitchell, 1979, dalam Waworuntu, 2003). Tindakan curang yang dilakukan seseorang disebabkan oleh keinginan untuk memaksimalkan keuntungan pribadi. Tindakan tersebut didorong oleh ketidakpuasan individu atas imbalan yang mereka peroleh dari pekerjaan yang mereka kerjakan. Kompensasi yang sesuai diharapkan dapat membuat individu merasa tercukupi sehingga individu tidak melakukan tindakan yang merugikan perusahaan termasuk melakukan kecurangan akuntansi. Manajemen akan beritndak sesuai dengan keinginan prinsipal (pemegang saham) jika mereka mendapatkan kompensasi yang sesuai dengan kinerjanya. Pemberian kompensasi ini dapat mengurangi kecenderungan kecurangan akuntansi. Penelitian Thoyibatun (2009) dan Randa dan Meliana (2009) menunjukkan bahwa kesesuaian kompensasi berpengaruh negatif terhadap kecenderungan kecurangan akuntansi. Oleh karena itu, diajukan hipotesis sebagai berikut:

H4: Kesesuaian kompensasi berpengaruh negatif terhadap kecenderungan kecurangan akuntansi

\section{Asimetri Informasi dan Perilaku Tidak Etis}

Asimetri informasi adalah ketidakseimbangan informasi yang dimiliki oleh prinsipal dan agen, ketika prinsipal tidak memiliki informasi yang cukup tentang kinerja agen sebaliknya, agen memiliki lebih banyak informasi mengenai kapasitas diri, lingkungan kerja dan perusahaan secara keseluruhan (Widyaningdyah, 2001). Asimetri informasi ini membuat manajemen memanfaatkan ketidakselarasan informasi untuk keuntungan mereka serta sekaligus merugikan pihak luar perusahaan, seperti membiaskan informasi yang terkait dengan investor (Scott, 2003). Lambert et al. (2001) menyatakan bahwa keberadaan asimetri informasi akan menimbulkan permasalahan perilaku yang disfungsional bagi agen (manajemen perusahaan). Hasil penelitian Dunk (1993) dan M. van Dyck (2000) dalam Wilopo (2006) menunjukkan hubungan antara asimetri informasi dengan perilaku yang 
tidak etis, baik yang dilakukan bawahan maupun pihak luar perusahaan (auditor eksternal). Penelitian Wilopo (2006) dan Hadi dan Prasaja (2015) menunjukkan bahwa asimetri informasi berpengaruh positif terhadap perilaku tidak etis. Oleh karena itu, diajukan hipotesis sebagai berikut:

H5: Asimetri informasi berpengaruh positif terhadap perilaku tidak etis

\section{Asimetri Informasi dan Kecenderungan Kecurangan Akuntansi}

Salah satu kendala yang akan muncul antara principal dan agent adalah adanya asimetri informasi. Asimetri informasi ini timbul karena principal tidak memiliki informasi yang cukup tentang kinerja agent dan agent memiliki lebih banyak informasi mengenai perusahaan secara keseluruhan (Nasution dan Doddy, 2007). Asimetri informasi yang terjadi antara principal dan agent mendorong agent untuk menyajikan informasi yang tidak sebenarnya, terutama jika informasi tersebut berkaitan dengan pengukuran kinerja agent. Hal ini memacu agent untuk memikirkan bagaimana angka akuntansi dapat digunakan sebagai sarana untuk memaksimalkan kepentingannya. Bila terjadi asimetri informasi, manajemen perusahaan membuat bias atau memanipulasi laporan keuangan sehingga dapat memperbaiki kompensasi dan reputasi manajemen, serta rasio-rasio keuangan perusahaan (Scott, 2003). Penelitian Wilopo (2006), Hadi dan Prasaja (2015), dan Randa dan Meliana (2009) menunjukkan bahwa asimetri informasi berpengaruh positif terhadap kecenderungan kecurangan akuntansi. Oleh karena itu, diajukan hipotesis sebagai berikut:

H6: Asimetri informasi berpengaruh positif terhadap kecenderungan kecurangan akuntansi

\section{Moralitas Manajemen dan Perilaku Tidak Etis}

Dalam teori atribusi, tindakan seorang pemimpin maupun orang yang diberikan wewenang dipengaruhi oleh atribut penyebab (Green and Mitchell, 1979, dalam Waworuntu, 2003). Moralitas merupakan suatu hal yang mempengaruhi tindakan dan perilaku seseorang. Dengan adanya moralitas yang baik maka manajemen diharapkan bertindak sesuai keinginan perusahaan dan menghindari tindakan menyimpang (perilaku tidak etis). Moralitas merupakan suatu hal yang mempengaruhi perilaku seorang individu. Karena moralitas merupakan salah satu faktor penting yang mempengaruhi tindakan dan perilaku seseorang. Moralitas yang buruk akan membuat individu cenderung berperilaku tidak etis. Penelitian ini berpendapat bahwa semakin tinggi tingkat moralitas manajemen, semakin rendah perilaku tidak etisnya.Penelitian Wilopo (2006), Fauwzi (2009), dan Bellyanti dan Rasmini (2016) menunjukkan bahwa moralitas manajemen berpengaruh negatif terhadap perilaku tidak etis. Oleh karena itu, diajukan hipotesis sebagai berikut:

H7: Moralitas manajemen berpengaruh negatif terhadap perilaku tidak etis

\section{Moralitas Manajemen dan Kecenderungan Kecurangan Akuntansi}

Dalam teori atribusi, tindakan seorang pemimpin maupun orang yang diberikan wewenang dipengaruhi oleh atribut penyebab (Green and Mitchell, 1979, dalam Waworuntu, 2003). Moralitas merupakan faktor penting dalam timbulnya 
kecurangan. Kecenderungan kecurangan akuntansi juga dipengaruhi oleh moralitas orang yang terlibat didalamnya. Dengan adanya moralitas yang baik diharapkan tindakan melakukan dalam kecurangan akan berkurang. Dalam teori perkembangan moral Kohlberg (1969) dalam Wilopo (2006) menyatakan bahwa moral berkembang melalui tiga tahapan, yaitu tahapan prakonvensional, tahapan konvensional, dan tahapan pasca-konvensional. Moralitas manajemen pada tahapan pasca-konvensional menunjukkan kematangan moral manajemen yang tinggi. Semakin tinggi tahapan dalam moralitas manajemen, maka manajer akan semakin berhati-hati dalam tindakannya yang dapat merugikan kepentingan pemegang saham. Dalam hal ini, manajer tidak hanya memperhatikan kepentingannya semata, tetapi juga kepentingan perusahaan dan sekitarnya. Jadi, semakin tinggi tingkat moralitas manajemen dalam suatu perusahaan, maka semakin manajemen berusaha menghindarkan diri dari kecenderungan kecurangan akuntansi (Wilopo, 2006). Penelitian Wilopo (2006), Fauwzi (2009), Randa dan Meliana (2009), dan Rahmawati (2012) menunjukkan bahwa moralitas manajemen berpengaruh negatif terhadap kecenderungan kecurangan akuntansi. Berdasarkan penjelasan dan penelitian terdahulu, peneliti menarik kesimpulan bahwa moralitas manajemen berpengaruh negatif terhadap kecenderungan kecurangan akuntansi, oleh karena itu dirumuskan hipotesis sebagai berikut:

H8: Moralitas manajemen berpengaruh negatif terhadap kecenderungan kecurangan akuntansi

\section{Perilaku Tidak Etis dan Kecenderungan Kecurangan Akuntansi}

Anik (2013) mengemukakan bahwa budaya yang etis dalam suatu perusahaan mempengaruhi tingkat kecenderungan kecurangan, yang artinya karyawan yang memiliki perilaku etis cenderung tidak akan melakukan kecurangan. Hal ini senada dengan pernyataan Wilopo (2006) yang mengemukakan bahwa semakin rendah karyawan berperilaku tidak etis, maka akan semakin rendah kecenderungan kecurangan, atau dengan kata lain semakin tinggi karyawan berperilaku etis, maka semakin tinggi pula karyawan untuk tidak melakukan kecurangan, yang artinya berpengaruh terhadap pencegahan kecurangan. Jadi dapat dikatakan semakin tinggi karyawan berperilaku tidak etis maka semakin tinggi kecenderungan untuk melakukan kecurangan akuntansi. Prinsip etika suatu manajemen diwakili oleh perilaku manajemen dalam pengelolaan perusahaan. Jika perilaku yang ditunjukan oleh manajemen cenderung tidak etis maka dapat menyebabkan terjadinya tindakan kecurangan akuntansi. Berbagai kajian dan penyampaian fakta, seperti oleh Green and Calderon (1999) dan Tang et al. (2003) menunjukkan bahwa perilaku tidak etis dalam bentuk penyalahgunaan wewenang dan kekuasaan, kedudukan, dan sumber daya perusahaan, mendorong manajemen melakukan kecurangan akuntansi. Penelitian Wilopo (2006), Thoyibatun (2009), dan Hadi dan Prasaja (2015) menunjukkan bahwa perilaku tidak etis berpengaruh positif terhadap kecenderungan kecurangan akuntansi. Oleh karena itu, diajukan hipotesis sebagai berikut:

H9: Perilaku tidak etis berpengaruh positif terhadap kecenderungan kecurangan akuntansi 


\section{METODE PENELITIAN \\ Jenis Penelitian}

Penelitian ini termasuk dalam jenis penelitian kuantitatif. Menurut Sugiyono (2009) metode penelitian kuantitatif dapat diartikan sebagai metode penelitian yang berlandaskan pada filsafat positivisme, digunakan untuk meneliti pada populasi atau sampel tertentu dengan tujuan untuk menguji hipotesis yang telah ditetapkan.

\section{Definisi Operasional dan Pengukuran Variabel Kecenderungan Kecurangan Akuntansi}

Kecenderungan didefinisikan sebagai "kecondongan, kesudian, keinginan, kesukaan hati akan.....". The Association of Certified Fraud Examiners (ACFE) atau Asosiasi Pemeriksa Kecurangan Bersertifikat mengklasifikasikan fraud (kecurangan) dalam beberapa klasifikasi, dan dikenal dengan istilah "Fraud Tree" yaitu: kecurangan laporan keuangan, penyalahgunaan aset, dan korupsi. Indikator kecenderungan kecurangan akuntansi adalah kecenderungan untuk melakukan kecurangan atas laporan keuangan, korupsi dan penyalahgunaan asset sesuai penjelasan dari ACFE. Variabel kecenderungan kecurangan akuntansi diukur menggunakan kuesioner yang terdiri dari lima item pernyataan yang diadopsi dari Wilopo (2006) dan disesuaikan oleh peneliti. Kuesioner ini menggunakan skala Likert 5 poin. Skala Likert 5 digunakan untuk mengukur respon subjek ke dalam 5 poin dengan interval yang sama. Skala ini terdiri dari angka 1 yang menunjukkan Sangat Tidak Setuju (STS), angka 2 Tidak Setuju (TS), angka 3 Netral (N), angka 4 Setuju (S), dan angka 5 Sangat Setuju (SS).

\section{Perilaku Tidak Etis}

Perilaku tidak etis adalah perilaku yang menurut keyakinan perseorangan dan normanorma sosial dianggap salah atau buruk (Griffin dan Ebert, 2006). Indikator variabel perilaku tidak etis adalah perilaku manajemen yang menyalahgunakan kedudukan (abuse position), perilaku manajemen yang menyalahgunakan sumber daya organisasi (abuse resource), perilaku manajemen yang menyalahgunakan kekuasaan (abuse power), dan perilaku manajemen yang tidak berbuat apa-apa (no action). Variabel perilaku tidak etis diukur menggunakan kuesioner yang terdiri dari lima item pernyataan yang diadopsi dari Wilopo (2006) dan disesuaikan oleh peneliti. Kuesioner ini menggunakan skala Likert 5 poin. Skala Likert 5 digunakan untuk mengukur respon subyek ke dalam 5 poin dengan interval yang sama. Skala ini terdiri dari angka 1 yang menunjukkan Sangat Tidak Setuju (STS), angka 2 Tidak Setuju (TS), angka 3 Netral (N), angka 4 Setuju (S), dan angka 5 Sangat Setuju (SS).

\section{Efektivitas Pengendalian Internal}

Menurut Lamp. SE No.5/22/DPNP Pedoman Standar Sistem Pengendalian Intern bagi Bank Umum yang dikeluarkan BI tanggal 29 September 2003, Pengendalian intern merupakan suatu mekanisme pengawasan yang ditetapkan oleh manajemen Bank secara berkesinambungan (on going basis), guna: menjaga dan mengamankan harta kekayaan Bank; menjamin tersedianya laporan yang lebih akurat; meningkatkan kepatuhan terhadap ketentuan yang berlaku; mengurangi dampak 
keuangan/kerugian, penyimpangan termasuk kecurangan/fraud, dan pelanggaran aspek kehati-hatian; serta meningkatkan efektivitas organisasi dan meningkatkan efisiensi biaya. Indikator efektivitas pengendalian internal menggunakan lima komponen utama pengendalian internal bank sesuai Lamp. SE No.5/22/DPNP Pedoman Standar Sistem Pengendalian Intern bagi Bank Umum yang dikeluarkan BI tanggal 29 September 2003, yaitu Pengawasan oleh Manajemen dan Kultur Pengendalian (Management Oversight and Control Culture), Identifikasi dan Penilaian Risiko (Risk Recognition and Assessment), Kegiatan Pengendalian dan Pemisahan Fungsi (Control Activities and Segregation of Duties), Sistem Akuntansi, Informasi, dan Komunikasi (Accountancy, Information and Communication), serta Kegiatan Pemantauan dan Tindakan Koreksi Penyimpangan/Kelemahan (Monitoring Activities and Correcting Deficiencies). Variabel efektivitas pengendalian internal diukur menggunakan kuesioner yang terdiri dari delapan item pernyataan yang diadopsi dari Wilopo (2006).

\section{Kesesuaian Kompensasi}

Menurut Hasibuan (2009) Kompensasi adalah semua pendapatan yang berbentuk uang maupun barang langsung atau tidak langsung yang diterima karyawan sebagai imbalan atas jasa yang diberikan kepada perusahaan. Indikator dari variabel kompensasi ini adalah gaji pokok, gaji variabel (seperti bonus dan insentif), dan tunjangan (seperti jaminan kesehatan dan fasilitas). Variabel kesesuaian kompensasi diukur menggunakan kuesioner yang terdiri dari sepuluh item pernyataan yang diadopsi dari Wilopo (2006) dan disesuaikan oleh peneliti. Kuesioner ini menggunakan skala Likert 5 poin. Skala Likert 5 digunakan untuk mengukur respon subyek ke dalam 5 poin dengan interval yang sama. Skala ini terdiri dari angka 1 yang menunjukkan Sangat Tidak Setuju (STS), angka 2 Tidak Setuju (TS), angka 3 Netral (N), angka 4 Setuju (S), dan angka 5 Sangat Setuju (SS).

\section{Asimetri Informasi}

Asimetri informasi merupakan situasi di mana terjadi ketidakselarasan informasi antara pihak yang memiliki atau menyediakan informasi dengan pihak yang membutuhkan informasi. Asimetri informasi ini membuat manajemen memanfaatkan ketidakselarasan informasi untuk keuntungan mereka serta sekaligus merugikan pihak luar perusahaan (Scott, 2003). Indikator asimetri informasi ini adalah dilihat dari bagaimana informasi terkait seluruh informasi yang terakit dengan transaksi keuangan perusahaan, isi dan angka laporan keuangan, faktor yang mempengaruhi pembuatan laporan keuangan, dan lika-liku pembuatan laporan keuangan apakah pihak luar dapat mengetahuinya dan memahaminya atau tidak. Variabel asimetri informasi diukur menggunakan kuesioner yang terdiri dari tujuh item pernyataan yang diadopsi dari Wilopo (2006) dan disesuaikan oleh peneliti.

\section{Moralitas Manajemen}

Moral adalah adalah istilah manusia menyebut ke manusia atau orang lainnya dalam tindakan yang memiliki nilai positif. Manusia yang tidak memiliki moral disebut amoral yang artinya dia tidak bermoral dan tidak memiliki nilai positif di mata manusia lainya (Rahmawati dan Soetik, 2012). Jadi moralitas manajemen adalah 
nilai-nilai positif yang dimiliki manajemen. Variabel moralitas manajemen diukur dari enam item pernyataan yang diadopsi dari Wilopo (2006) dan disesuaikan oleh peneliti yang mengukur setiap tahapan moralitas manajemen melalui kasus etika akuntansi. Indikator pengukuran moralitas manajemen dilihat dari tahap-tahap perkembangan moral yaitu tingkat pra konvensional, konvensional, dan pascakonvensional. Setiap tahapan moralitas manajemen menggunakan skala Likert 5 poin.

\section{Populasi dan Sampel}

Populasi dalam penelitian ini adalah seluruh karyawan bagian akuntansi dan keuangan pada bank konvensional di kota Bengkulu. Sampel dalam penelitian ini ditentukan dengan menggunakan teknik purposive sampling. Purposive sampling adalah teknik penentuan sampel dengan pertimbangan tertentu (Sugiyono, 2012). Kriteria responden yang ditentukan untuk penelitian ini adalah merupakan kepala dan karyawan bank bagian akuntansi dan keuangan.

\section{Metode Pengumpulan Data}

Data yang digunakan dalam penelitian ini adalah data primer. Data primer menurut Sarwono (2006) adalah data yang berasal dari sumber asli atau pertama. Data diperoleh melalui pengisian kuesioner oleh responden, jawaban dari isian kuesioner oleh responden tersebut akan diolah lebih lanjut untuk mengujihipotesis dari penelitian ini.

\section{Metode Analisis Data \\ Statistik Deskriptif}

Statistik deskriptif digunakan untuk menganalisis dan menyajikan sebagian besar data. Statistik deskriptif menampilkan nilai rata-rata (mean), ukuran penyebaran (standar deviasi), dan bentuk distribusi (nilai minimum dan maksimum) data (Cooper dan Schindler, 2012).

\section{Analisis Data}

Analisis data dalam penelitian ini menggunakan pendekatan Partial Least Square (PLS). Menurut Ghozali (2014), PLS merupakan pendekatan alternatif yang bergeser dari pendekatan SEM berbasis kovarian menjadi berbasis varian. Pengujian dengan menggunakan PLS pada dasarnya terdiri atas dua macam pengujian, yaitu:

\section{Outer Model (Model Pengukuran)}

Pada pengujian outer model ini dilakukan dua pengujian yaitu menguji validitas dan pengujian reliabilitas. Validitas yang digunakan dalam penelitian ini adalah validitas konvergen dan validitas diskriminan.Validitas konvergen dari model pengukuran dengan refleksif indikator dinilai berdasarkan korelasi antara item score/component score yang dihitung dengan PLS. factor loading menggambarkan besarnya korelasi antar setiap item pengukuran (indikator) dengan konstruknya. Ukuran refleksif individual dikatakan tinggi jika berkorelasi lebih dari 0,70 dengan konstruk yang ingin diukur (Ghozali, 2014). Ada dua prosedur yang digunakan untuk menilai validitas diskriminan (Chin, 1998). (1) Validitas diskriminan indikator reflektif dapat dilihat dengan 
membandingkan korelasi indikator suatu konstruk dengan korelasi indikator tersebut dengan konstruk lainnya berdasarkan crossloading (Ghozali, 2014). Jika korelasi indikator konstruk memiliki nilai lebih tinggi dibandingkan dengan korelasi indikator tersebut terhadap konstruk lain, maka dikatakan konstruk memiliki validitas diskriminan yang tinggi (Chin, 1998). (2) Menguji Average Variance Extracted (AVE) untuk memastikan bahwa setiap konstruk memberikan variance yang lebih besar dengan ukurannya dari pada konstruk laten lainnya dalam model penelitian. Validitas dikatakan memiliki nilai yang baik berdasarkan rule of thumb jika nilai akar dari AVE untuk konstruk individual lebih besar dari nilai korelasi antar konstruk dengan konstruk lain dalam model (Chin, 1998) dan harus lebih besar daripada nilai yang direkomendasikan yaitu 0,5 (Fornell dan Larcker, 1981). Reliabilitas konstruk dalam penelitian ini akan diukur dengan menggunakan composite reliability. Untuk dapat dikatakan suatu konstruk reliabel, maka nilai composite reliability harus lebih besar dari 0,7 (Abdillah dan Jogiyanto, 2015). Dalam PLS, uji reliabilitas diperkuat dengan adanya cronbach alpha dimana konsistensi dari setiap jawaban diujikan. Untuk dapat dikatakan suatu konstruk reliabel, maka nilai cronbach alpha harus > 0,6 (Abdillah dan Jogiyanto, 2015).

\section{Inner Model (Model Struktural)}

Menurut Ghozali (2014) Pengujian inner model atau model struktural dilakukan untuk melihat hubungan antara konstruk, nilai signifikansi dan $R$-square dari model penelitian. Model struktural dievaluasi dengan menggunakan $R$-square untuk konstruk dependen dan uji $t$ serta signifikansi dari koefisien parameter jalur struktural. Dalam menilai model dengan PLS dimulai dengan melihat $R$-square untuk setiap variabel laten dependen. Perubahan nilai $R$ - square dapat digunakan untuk menilai pengaruh variabel laten independen tertentu terhadap variabel laten dependen apakah mempunyai pengaruh yang substantif (Ghozali, 2014).

\section{Uji Hipotesis}

Pengujian hipotesis dilakukan dengan proses bootstrapping/resampling bootstrapping. Pengujian hipotesis yang diajukan dapat dilihat dari besarnya nilai tstatistik. Kriteria untuk menolak dan menerima hubungan yang diajukan dapat dilihat dari perbandingan antar nilai t- statistik dan t-tabel. Jika nilai t-statistik > t-tabel $(1,64)$ makahipotesis yang diajukan diterima (Ghozali, 2014).

\section{HASIL PENELITIAN DAN PEMBAHASAN}

\section{Statistik Deskriptif}

Statistik deskriptif data penelitian ini dapat dilihat dari rata-rata (mean) teoritis dan aktual, nilai minimum, nilai maksimum, dan nilai standar deviasi. Statistik deskriptif variabel penelitian digunakan untuk memberikan gambaran tentang tanggapan responden terhadap variabel-variabel penelitian.

Berikut ini adalah tabel hasil pengukuran statistik deskriptif dapat dilihat pada Tabel 4.1: 
Tabel 4.1 Statistik Deskriptif

\begin{tabular}{|c|c|c|c|c|c|c|c|c|}
\hline \multirow[t]{2}{*}{ Variabel } & \multirow[t]{2}{*}{$\mathbf{N}$} & \multicolumn{2}{|c|}{$\begin{array}{l}\text { Kisaran } \\
\text { Teoritis }\end{array}$} & \multirow[t]{2}{*}{$\begin{array}{c}\text { Mean } \\
\text { Teoritis }\end{array}$} & \multicolumn{2}{|c|}{$\begin{array}{l}\text { Kisaran } \\
\text { Aktual }\end{array}$} & \multirow{2}{*}{$\begin{array}{l}\text { Mean } \\
\text { Aktua } \\
\text { l }\end{array}$} & \multirow{2}{*}{$\begin{array}{c}\text { Std. } \\
\text { Deviatio } \\
n\end{array}$} \\
\hline & & Min & Maks & & Min & $\begin{array}{c}\text { Mak } \\
\text { S }\end{array}$ & & \\
\hline $\begin{array}{l}\text { Efektivitas } \\
\text { Pengendalian } \\
\text { Internal }\end{array}$ & 50 & 8 & 40 & 24 & 8 & 20 & 13,38 & 3,374 \\
\hline $\begin{array}{l}\text { Kesesuaian } \\
\text { Kompensasi }\end{array}$ & 50 & 10 & 50 & 30 & 37 & 50 & 42,20 & 4,347 \\
\hline $\begin{array}{l}\text { Asimetri } \\
\text { Informasi }\end{array}$ & 50 & 7 & 35 & 21 & 23 & 35 & 29,10 & 3,358 \\
\hline $\begin{array}{l}\text { Moralitas } \\
\text { Manajemen }\end{array}$ & 50 & 6 & 30 & 18 & 6 & 15 & 10,58 & 2,785 \\
\hline $\begin{array}{l}\text { Perilaku Tidak } \\
\text { Etis }\end{array}$ & 50 & 5 & 25 & 15 & 5 & 14 & 8,72 & 2,681 \\
\hline $\begin{array}{l}\text { Kecenderungan } \\
\text { Kecurangan } \\
\text { Akuntansi }\end{array}$ & 50 & 5 & 25 & 15 & 5 & 11 & 8,24 & 2,352 \\
\hline
\end{tabular}

Sumber: Data Primer diolah, 2017

Tabel 4.1 merupakan hasil pengukuran statistik deskriptif terhadap semua variabel dari 50 responden. Pada tabel tersebut disajikan kisaran teoritis yang merupakan nilai yang diukur dari skor tertinggi atau terendah dikalikan jumlah pernyataan, sedangkan kisaran aktual merupakan nilai skor dari yang terendah sampai skor yang tertinggi, mean (rata-rata) merupakan hasil penjumlahan nilai seluruh data dibagi dengan banyak data, sementara standar deviasi adalah akar dari jumlah kuadrat dari selisih nilai data dengan rata-rata dibagi dengan banyaknya data.

Berdasarkan tabel 4.1, variabel efektivitas pengendalian internal memiliki nilai rata- rata teoritis sebesar 24, sedangkan untuk rata-rata kisaran aktualnya sebesar 13,38 dan standar deviasinya sebesar 3,374. Nilai kisaran aktual minimal sebesar 8 dan maksimal sebesar 20 menunjukkan bahwa jawaban responden pada variabel efektivitas pengendalian internal di kisaran angka 1 dan 2 yang artinya bahwa responden menilai sangat tidak setuju dan tidak setuju memiliki pengendalian yang kurang efektif. Nilai rata-rata aktual dibawah nilai rata-rata teoritis mengindikasikan bahwa jawaban responden rata-rata menilai tidak setuju bahwa perusahaan perbankan memiliki pengendalian yang kurang efektif. Hal ini menunjukkan bahwa pengendalian internal di perusahaan perbankan tempat responden bekerja sudah efektif. Variabel kesesuaian kompensasi memiliki nilai rata-rata teoritis sebesar 30, sedangkan untuk rata-rata kisaran aktualnya sebesar 42,20 dan standar deviasinya sebesar 4,347. Nilai kisaran aktual minimal sebesar 37 dan maksimal sebesar 50 menunjukkan bahwa jawaban responden pada variabel 
kesesuaian kompensasi di kisaran angka 3 dan 5 yang artinya bahwa responden menilai setuju dan sangat setuju kompensasi yang mereka terima sudah sesuai. Nilai rata-rata aktual diatas nilai rata-rata teoritis mengindikasikan bahwa jawaban responden rata-rata menilai setuju bahwa kompensasi yang mereka terima dari perusahaan perbankan tempat mereka bekerja sudah sesuai.

Berdasarkan tabel 4.1, variabel asimetri informasi memiliki nilai rata-rata teoritis sebesar 21, sedangkan untuk rata-rata kisaran aktualnya sebesar 29,10 dan standar deviasinya sebesar 3,358. Nilai kisaran aktual minimal sebesar 23 dan maksimal sebesar 35 menunjukkan bahwa jawaban responden pada variabel asimetri informasi di kisaran angka 3 dan 5 yang artinya bahwa responden menilai setuju dan sangat setuju bahwa terjadi asimetri informasi yang cukup tinggi. Nilai rata-rata aktual diatas nilai rata-rata teoritis, hal ini mengindikasikan bahwa jawaban responden rata-rata menilai setuju bahwa terjadi asimetri informasi yang cukup tinggi di perusahaan perbankan tempat responden bekerja. Variabel moralitas manajemen memiliki nilai rata-rata teoritis sebesar 18, sedangkan untuk rata-rata kisaran aktualnya sebesar 25,42 dan standar deviasinya sebesar 2,785. Nilai kisaran aktual minimal sebesar 6 dan maksimal sebesar 15 menunjukkan bahwa jawaban responden pada variabel moralitas manajemen di kisaran angka 1 dan 2 yang artinya bahwa responden menilai sangat tidak setuju dan tidak setuju memiliki moralitas manajemen yang kurang baik. Nilai rata-rata aktual dibawah nilai ratarata teoritis mengindikasikan bahwa jawaban responden rata-rata menilai tidak setuju bahwa karyawan memiliki moralitas manajemen yang kurang baik, sehingga hal ini menunjukkan bahwa moral manajemen dan karyawan di perusahaan perbankan tempat responden bekerja tersebut sudah baik.

Berdasarkan tabel 4.1, variabel perilaku tidak etis memiliki nilai rata-rata teoritis sebesar 15, sedangkan untuk rata-rata kisaran aktualnya sebesar 8,72 dan standar deviasinya sebesar 2,681. Nilai kisaran aktual minimal sebesar 5 dan maksimal sebesar 14 menunjukkan bahwa jawaban responden pada variabel perilaku tidak etis di kisaran angka 1 dan 2 yang artinya bahwa responden menilai sangat tidak setuju dan tidak setuju memiliki perilaku yang kurang etis. Nilai rata-rata aktual jauh dibawah nilai rata-rata teoritis mengindikasikan bahwa jawaban responden sangat rendah sehingga responden menilai bahwa perilaku karyawan di perusahaan perbankan tempat responden bekerja sudah etis.

Variabel kecenderungan kecurangan akuntansi memiliki nilai rata-rata teoritis sebesar 15 , sedangkan untuk rata-rata kisaran aktualnya sebesar 8,24 dan standar deviasinya sebesar 2,352. Nilai kisaran aktual minimal sebesar 5 dan maksimal sebesar 11 menunjukkan bahwa jawaban responden pada variabel kecenderungan kecurangan akuntansi di kisaran angka 1 dan 2 yang artinya bahwa responden menilai sangat tidak setuju dan tidak setuju pernah terjadi kecurangan akuntansi di perusahaan tempat responden bekerja. Nilai rata-rata aktual dibawah nilai rata-rata teoritis, hal ini mengindikasikan bahwa jawaban responden sangat rendah, sehingga responden menilai bahwa sangat rendah atau sangat kecil kemungkinan 
kecenderungan melakukan kecurangan akuntansi di perusahaan perbankan tempat responden bekerja.

\section{Analisis Data}

\section{Evaluasi Outer Model}

Penelitian ini menggunakan model persamaan struktural yang dianalisis dengan menggunakan program SmartPLS 2.0 M3. Outer/measurement model (model pengukuran) digunakan untuk mengetahui validitas dan reliabilitas yang menghubungkan indikator dengan variabel latennya. Evaluasi outer model dilakukan dengan menggunakan PLS Algorithm. Convergent validity dari measurement model dengan indikator reflektif dapat dilihat dari korelasi antara score item/indikator dengan score konstruknya. Indikator individu dianggap reliable jika memiliki nilai korelasi di atas 0,7. Gambar 4.1 menunjukkan tampilan hasil PLS Algorithm.

Pada gambar 4.1 menunjukkan bahwa semua indikator memiliki skor di atas 0,70 kecuali indikator EPI2, EPI8, KK6, KK7, KK8, dan PTE2 yang memiliki skor kurang dari 0,70 . Selanjutnya model di re- estimasi kembali dengan mengeliminasi indikator tersebut.

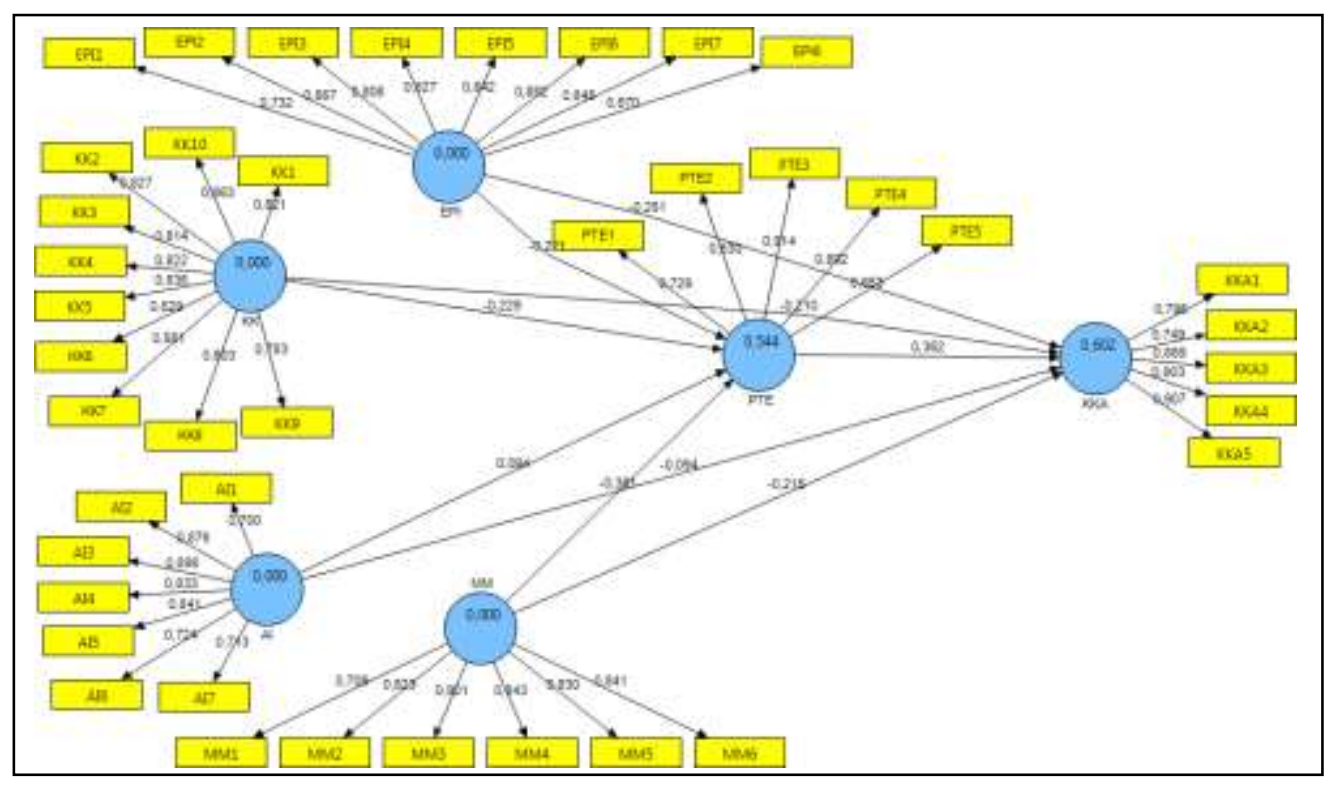

Sumber: data primer diolah, 2017

\section{Gambar 4.1 Tampilan Hasil PLS Alghoritm Sebelum Eliminasi}

Gambar 4.2 berikut menunjukkan tampilan hasil PLS Algorithm setelah indikator tersebut dieliminasi dan model dire-estimasi kembali. semua indikator memiliki skor di atas 0,70 kecuali indikator PTE1 yang memiliki skor kurang dari 0,70 yang sebelum dieliminasi memiliki skor lebih dari 0,70 tetapi setelah dieliminasi memiliki skor kurang dari 0,70 . Selanjutnya model di re-estimasi kembali dengan mengeliminasi indikator tersebut. 


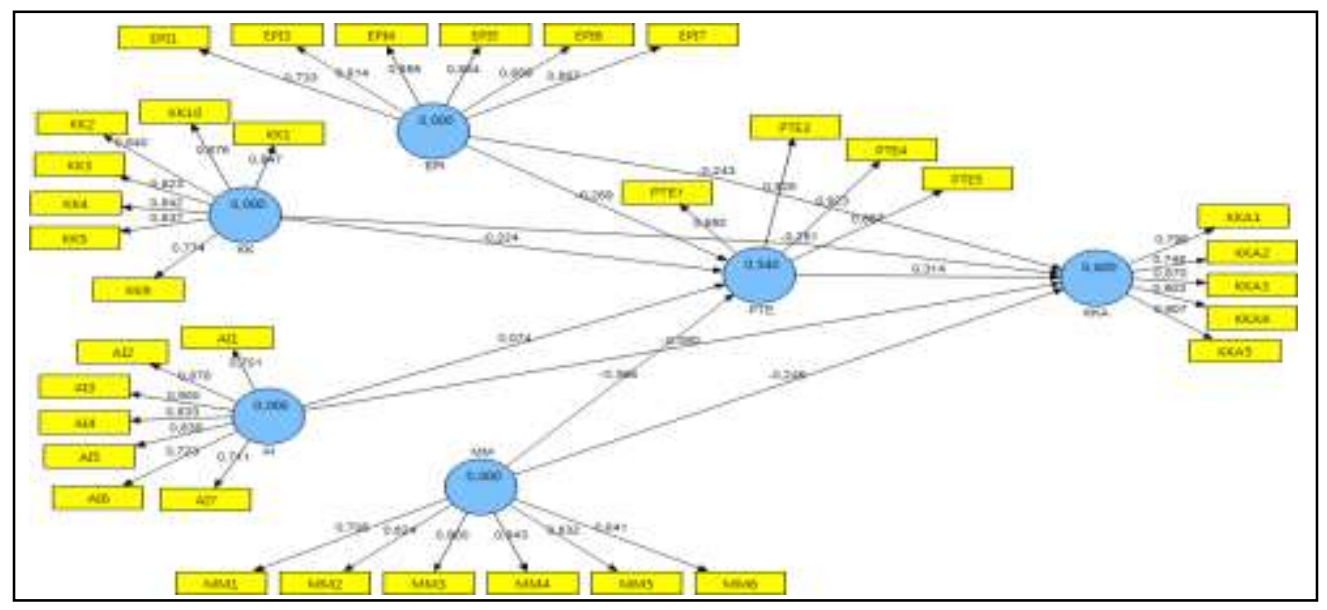

Sumber: data primer diolah, 2017

\section{Gambar 4.2 Tampilan Hasil PLS Algorithm Setelah Eliminasi 1}

Gambar 4.3 menunjukkan bahwa semua indikator memiliki skor di atas 0,70 dan tidak ada lagi indikator yang memiliki skor kurang dari 0,70. Untuk lebih jelasnya dapat dilihat pada Lampiran 2 Tabel Outer Loading Setelah Eliminasi 2. Berdasarkan gambar 4.2 dapat disimpulkan bahwa konstruk telah memenuhi kriteria convergent validity. Jadi untuk tahapan atau uji selanjutnya indikator EPI2, EPI8, KK6, KK7, KK8, PTE1, dan PTE2 tidak diikutkan lagi dalam model.

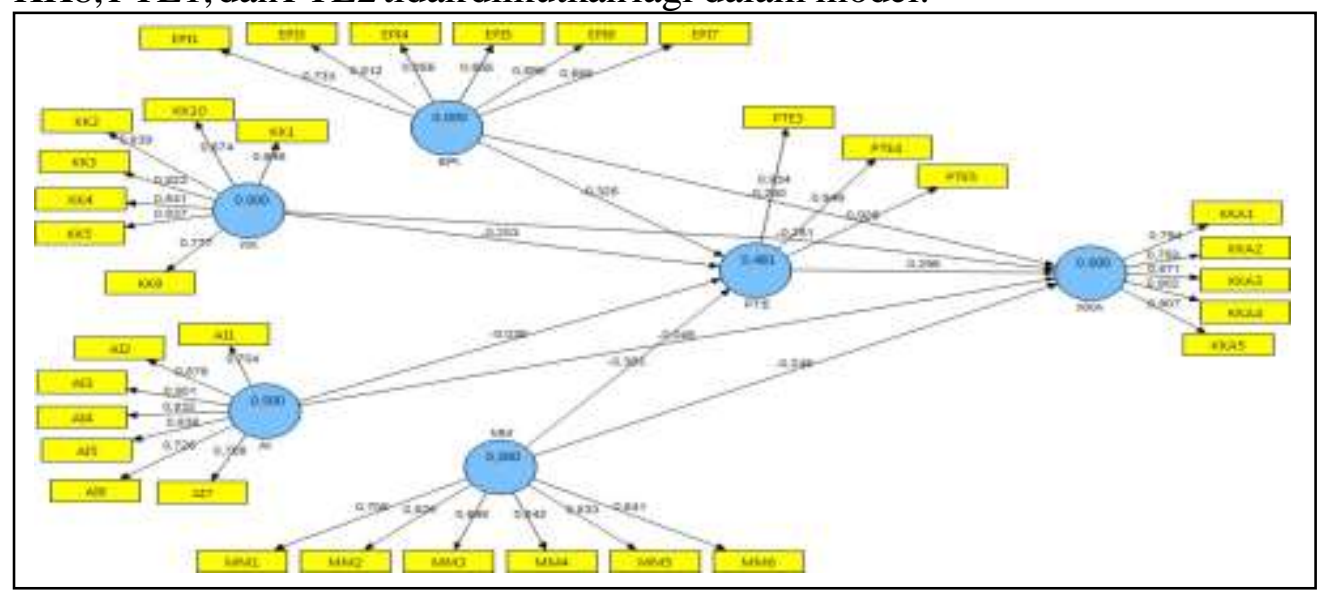

Sumber: data primer diolah, 2017

\section{Gambar 4.3 Tampilan Hasil PLS Algorithm Setelah Eliminasi 2}

Ada dua prosedur atau metode yang digunakan untuk menilai validitas diskriminan. Metode pertama yaitu membandingkan korelasi indikator suatu konstruk dengan korelasi indikator tersebut dengan konstruk lainnya dengan melihat nilai dari cross loading antara indikator dan konstruknya. Hasilnya menunjukkan adanya validitas diskriminan yang baik karena nilai korelasi indikator terhadap konstruknya lebih tinggi dibandingkan nilai korelasi indikator dengan konstruk lainnya. Dengan demikian, konstruk laten memprediksi indikator pada blok mereka lebih baik dibandingkan dengan indikator di blok yang lain.Metode yang kedua adalah dengan melihat nilai AVE (Average Variance Extracted) dan nilai akar dari AVE untuk setiap konstruk dengan korelasi antara 
konstruk dengan konstruk lainnya dalam model. Dipersyaratkan model yang baik kalau nilai akar AVE untuk konstruk individual lebih besar dari nilai korelasi antar konstruk dengan konstruk lainnya dalam model dan nilai AVE masing-masing konstruk nilainya harus lebih besar dari 0,50 . Tabel 4.2 berikut menunjukkan hasil output nilai AVE dari model.

AVE (Average Variance Extracted)

\begin{tabular}{|l|r|}
\hline \multicolumn{1}{|c|}{ Variabel } & $\begin{array}{c}\text { AVE (Average Variance } \\
\text { Extracted })\end{array}$ \\
\hline Efektivitas Pengendalian Internal & 0,7003 \\
\hline Kesesuaian Kompensasi & 0,6961 \\
\hline Asimetri Informasi & 0,6426 \\
\hline Moralitas Manajemen & 0,6830 \\
\hline Perilaku Tidak Etis & 0,8774 \\
\hline Kecenderungan Kecurangan Akuntansi & 0,7174 \\
\hline
\end{tabular}

Sumber: data primer diolah, 2017

Berdasarkan tabel 4.2 di atas menunjukkan bahwa nilai AVE (Average Variance Extracted) untuk konstruk efektivitas pengendalian internal, kesesuaian kompensasi, asimetri informasi, moralitas manajemen, perilaku tidak etis, dan kecenderungan kecurangan akuntansi memiliki nilai lebih besar daripada 0,50 .

Tabel 4.3

Nilai Akar AVE (Average Variance Extracted) dan Korelasi antar Variabel Laten

\begin{tabular}{|l|l|l|l|l|l|l|}
\hline & $\begin{array}{l}\text { Efektivita } \\
\mathbf{S} \\
\text { Pengendal } \\
\text { ian } \\
\text { Internal }\end{array}$ & $\begin{array}{l}\text { Kesesuaian } \\
\text { Kompensas } \\
\text { int }\end{array}$ & $\begin{array}{l}\text { Asimetri } \\
\text { Informasi }\end{array}$ & $\begin{array}{l}\text { Moralitas } \\
\text { Manajemen }\end{array}$ & $\begin{array}{l}\text { Perilaku } \\
\text { Tidak } \\
\text { Etis }\end{array}$ & $\begin{array}{l}\text { Kecende } \\
\text { rungan } \\
\text { Kecura } \\
\text { ngan } \\
\text { Akunta } \\
\text { nsi }\end{array}$ \\
\hline $\begin{array}{l}\text { Efektivitas } \\
\text { Pengendalia } \\
\text { n Internal }\end{array}$ & $\mathbf{0 , 8 3 6 8}$ & & & & & \\
\hline $\begin{array}{l}\text { Kesesuaian } \\
\text { Kompensasi }\end{array}$ & 0,3686 & $\mathbf{0 , 8 3 4 3}$ & & & & \\
\hline $\begin{array}{l}\text { Asimetri } \\
\text { Informasi }\end{array}$ & $-0,7888$ & $-0,3876$ & $\mathbf{0 , 8 0 1 6}$ & & & \\
\hline $\begin{array}{l}\text { Moralitas } \\
\text { Manajemen }\end{array}$ & 0,4880 & 0,3768 & $-0,6046$ & $\mathbf{0 , 8 2 6 4}$ & & \\
\hline $\begin{array}{l}\text { Perilaku } \\
\text { Tidak } \\
\text { Etis }\end{array}$ & $-0,5577$ & $-0,4526$ & 0,5291 & $-0,5951$ & $\mathbf{0 , 9 3 6 7}$ & \\
\hline $\begin{array}{l}\text { Kecenderung } \\
\text { a n } \\
\text { Kecurangan } \\
\text { Akuntansi }\end{array}$ & $-0,5761$ & $-0,5551$ & 0,5436 & $-0,6072$ & 0,6653 & $\mathbf{0 , 8 4 7 0}$ \\
\hline
\end{tabular}

Sumber: data primer diolah, 2017

Berdasarkan tabel 4.3 di atas, untuk setiap angka yang ditebalkan adalah nilai akar AVE (Average Variance Extracted) dari setiap konstruk dan angka yang tidak ditebalkan adalah nilai korelasi antar konstruk dengan konstruk lainnya dalam 
model. Dilihat dari tabel 4.3 tersebut dapat disimpulkan bahwa akar AVE semua konstruk lebih tinggi dari korelasi antara konstruk tersebut dengan konstruk lainnya. Jadi dapat disimpulkan dari hasil output tabel 4.2 dan table 4.1 di atas bahwa semua konstruk memenuhi kriteria validitas diskriminan. Disamping uji validitas konstruk, dilakukan juga uji reliabilitas konstruk yang diukur dengan composite reliability dan diperkuat dengan cronbachs alpha dari blok indikator yang mengukur konstruk. Hasil pengujian composite reliability dan cronbachs alpha dapat dilihat pada tabel 4.4. Sebuah konstruk dinyatakan reliabel jika memiliki nilai composite reliability $>0,70$ dan cronbachs alpha $>0,60$.

Tabel 4.4

Composite Reliability dan Cronbachs Alpha

\begin{tabular}{|l|c|c|}
\hline \multicolumn{1}{|c|}{ Variabel } & $\begin{array}{l}\text { Composite } \\
\text { Reliability }\end{array}$ & $\begin{array}{l}\text { Cronbachs } \\
\text { Alpha }\end{array}$ \\
\hline $\begin{array}{l}\text { Efektivitas Pengendalian } \\
\text { Internal }\end{array}$ & 0,9332 & 0,9135 \\
\hline Kesesuaian Kompensasi & 0,9412 & 0,9284 \\
\hline Asimetri Informasi & 0,9258 & 0,9061 \\
\hline Moralitas Manajemen & 0,9279 & 0,9060 \\
\hline Perilaku Tidak Etis & 0,9555 & 0,9302 \\
\hline $\begin{array}{l}\text { Kecenderungan } \\
\text { Kecurangan Akuntansi }\end{array}$ & 0,9266 & 0,9009 \\
\hline
\end{tabular}

Sumber: data primer diolah, 2017

Dari hasil output smartPLS diatas semua konstruk memiliki nilai composite reliability di atas 0,70 dan Cronbachs alpha semua konstruk memiliki nilai di atas 0,60. Jadi dapat disimpulkan dari hasil output composite reliability dan cronbachs alpha di atas bahwa semua konstruk telah memenuhi kriteria uji reliabilitas.

\section{Evaluasi Inner Model (Model Pengukuran)}

Model struktural dievaluasi dengan menggunakan $R$-square untuk konstruk dependen (endogen) dan uji $t$ serta signifikansi dari koefisien parameter jalur struktural. Untuk nilai R- square konstruk dependen (endogen) dapat dilihat pada tabel 4.5 berikut.

Tabel 4.5 R-Square

\begin{tabular}{|r|c|}
\hline Variabel & R Square \\
\hline Perilaku Tidak Etis & 0,4813 \\
\hline $\begin{array}{l}\text { Kecenderungan Kecurangan } \\
\text { Akuntansi }\end{array}$ & 0,5998 \\
\hline
\end{tabular}

Sumber: data primer diolah, 2017

Uji yang kedua adalah melihat signifikansi dengan melihat nilai koefisien parameter dan nilai signifikansi t-statistik. Untuk menilai signifikansi model prediksi dalam pengujian model struktural, dapat dilihat dari nilai t-statistic antar variabel independen ke variabel dependen. Dalam PLS pengujian secara statistik setiap hubungan yang dihipotesiskan dilakukan dengan menggunakan simulasi yaitu membandingkan nilai t-statistic dengan t- tabel signifikansi $\alpha=5 \%(1,64)$. 
Jika nilai t-statistic $>\mathrm{t}$-tabel maka hipotesis di terima dan jika nilai $\mathrm{t}$-statistic $<\mathrm{t}$ tabel maka hipotesis ditolak. Signifikansi model dalam pengujian model struktural dapat dilihat dari nilai t-statistic dalam tabel path coefficient. Tabel path coefficient pada output SmartPLS dapat dilihat pada tabel 4.6.

Tabel 4.6

Path Coefficient (Mean, STDEV, t-Values)

\begin{tabular}{|c|c|c|c|c|c|c|}
\hline & $\begin{array}{l}\text { Original } \\
\text { Sample } \\
(\mathbf{O})\end{array}$ & $\begin{array}{l}\text { Sample } \\
\text { Mean } \\
(\mathrm{M})\end{array}$ & $\begin{array}{l}\text { Standard } \\
\text { Deviation } \\
\text { (STDEV) }\end{array}$ & $\begin{array}{l}\text { Standard } \\
\text { Error } \\
\text { (STERR) }\end{array}$ & $\begin{array}{l}\text { t-statistics } \\
(\mid \text { O/STERR } \mid\end{array}$ & t-tabel \\
\hline $\begin{array}{l}\text { EPI -> } \\
\text { PTE }\end{array}$ & $-0,3264$ & $-0,3407$ & 0,1398 & 0,1398 & 2,3345 & 1,64 \\
\hline $\begin{array}{l}\text { EPI -> } \\
\text { KKA }\end{array}$ & $-0,2295$ & $-0,2370$ & 0,1012 & 0,1012 & 2,2667 & 1,64 \\
\hline $\begin{array}{l}\text { KK -> } \\
\text { PTE }\end{array}$ & $-0,2030$ & $-0,2178$ & 0,0706 & 0,0706 & 2,8737 & 1,64 \\
\hline $\begin{array}{l}\text { KK -> } \\
\text { KKA }\end{array}$ & $-0,2607$ & $-0,2733$ & 0,0714 & 0,0714 & 3,6498 & 1,64 \\
\hline $\begin{array}{l}\text { AI -> } \\
\text { PTE }\end{array}$ & $-0,0383$ & $-0,0500$ & 0,1287 & 0,1287 & 0,2977 & 1,64 \\
\hline $\begin{array}{l}\text { AI -> } \\
\text { KKA }\end{array}$ & $-0,0448$ & $-0,0516$ & 0,1011 & 0,1011 & 0,4436 & 1,64 \\
\hline $\begin{array}{l}\text { MM -> } \\
\text { PTE }\end{array}$ & $-0,3825$ & $-0,3770$ & 0,0763 & 0,0763 & 5,0105 & 1,64 \\
\hline $\begin{array}{l}\text { MM - } \\
>\text { KKA }\end{array}$ & $-0,2485$ & $-0,2580$ & 0,0729 & 0,0729 & 3,4057 & 1,64 \\
\hline $\begin{array}{l}\text { PTE - } \\
>\text { KKA }\end{array}$ & 0,2951 & 0,2775 & 0,0844 & 0,0844 & 3,4950 & 1,64 \\
\hline
\end{tabular}

Sumber: data primer diolah, 2017

\section{Pengujian Hipotesis}

Berdasarkan tabel 4.6 hipotesis yang diajukan dilihat dengan membandingkan tstatistik dengan t-tabel, jika t-statistik > t-tabel $(1,64)$ maka hipotesis diterima. Untuk melihat arahnya dlihat pada bagian original sample apakah koefisiennya bertanda positif atau negatif. Dari tabel 4.6 dengan membandingkan t-statistik dengan t-tabel dan melihat koefisien pada original sample, terlihat bahwa variabel efektivitas pengendalian internal berpengaruh negatif terhadap perilaku tidak etis dan kecenderungan kecurangan akuntansi, jadi hipotesis $\mathrm{H} 1$ dan hipotesis $\mathrm{H} 2$ diterima. Variabel kesesuaian kompensasi berpengaruh negatif terhadap perilaku tidak etis dan kecenderungan kecurangan akuntansi, jadi hipotesis $\mathrm{H} 3$ dan hipotesis H4 diterima. Variabel asimetri informasi tidak berpengaruh terhadap perilaku tidak etis dan kecenderungan kecurangan akuntansi, jadi hipotesis H5 dan hipotesis H6 ditolak. Variabel moralitas manajemen berpengaruh negatif terhadap perilaku tidak etis dan kecenderungan kecurangan akuntansi, jadi hipotesis $\mathrm{H} 7$ dan 
hipotesis $\mathrm{H} 8$ diterima. Variabel perilaku tidak etis berpengaruh negatif terhadap kecenderungan kecurangan akuntansi, jadi hipotesis $\mathrm{H} 9$ diterima.

Hipotesis pertama (1) yang menyatakan bahwa efektivitas pengendalian internal berpengaruh negatif terhadap perilaku tidak etis secara empiris terbukti didukung. Hasil penelitian ini menunjukkan bahwa semakin baik pengendalian internal pada perusahaan perbankan tempat responden bekerja maka akan semakin rendah perilaku tidak etis karyawan akuntansi dan keuangan pada perusahaan perbankan tersebut. Hasil pada hipotesis 1 mendukung penelitian Wilopo (2006), Thoyibatun (2009), Fauwzi (2009), Yuli (2013), dan Bellyanti dan Rasmini (2016) menunjukkan bahwa efektivitas pengendalian internal berpengaruh negatif terhadap perilaku tidaketis.

Hipotesis kedua (2) yang menyatakan bahwa efektivitas pengendalian internal berpengaruh negatif terhadap kecenderungan kecurangan akuntansi secara empiris terbukti didukung. Hasil penelitian ini menunjukkan bahwa semakin efektif pengendalian internal di perusahaan perbankan maka akan semakin rendah kecenderungan melakukan kecurangan akuntansi pada perusahaan perbankan tersebut. Hasil penelitian ini mendukung hasil penelitian Wilopo (2006), Thoyibatun (2009), Fauwzi (2009), Randa dan Meliana (2009), dan Rahmawati (2012) yang menemukan bahwa efektivitas pengendalian internal berpengaruh negatif terhadap kecenderungan kecurangan akuntansi.

Hipotesis ketiga (3) yang menyatakan bahwa kesesuaian kompensasi berpengaruh negatif terhadap perilaku tidak etis secara empiris terbukti didukung. Hasil penelitian ini menunjukkan bahwa semakin sesuai kompensasi yang diterima responden pada perusahaan perbankan tempat responden bekerja maka akan semakin rendah perilaku tidak etis karyawan akuntansi dan keuangan pada perusahaan perbankan tersebut. Hasil pada hipotesis 3 mendukung penelitian Thoyibatun (2009) dan Yuli (2013) yang menemukan bahwa kesesuaian kompensasi berpengaruh negatif terhadap perilaku tidak etis. Hipotesis keempat (4) yang menyatakan bahwa kesesuaian kompensasi berpengaruh negatif terhadap kecenderungan kecurangan akuntansi secara empiris terbukti didukung. Hasil penelitian ini menunjukkan bahwa semakin sesuai kompensasi yang diterima responden pada perusahaan perbankan tempat responden bekerja maka akan semakin rendah kecenderungan melakukan kecurangan akuntansi pada perusahaan perbankan tersebut. Hasil pada hipotesis 4 mendukung penelitian Thoyibatun (2009) dan Randa dan Meliana (2009) yang menemukan bahwa kesesuaian kompensasi berpengaruh negatif terhadap kecenderungan kecurangan akuntansi.

Hipotesis kelima (5) yang menyatakan bahwa asimetri informasi berpengaruh positif terhadap perilaku tidak etis secara empiris tidak terbukti. Hal ini berarti menunjukkan bahwa tidak ada pengaruh antara asimetri informasi terhadap perilaku tidak etis. Tidak berpengaruhnya asimetri informasi terhadap perilaku tidak etis ini membuktikan bahwa adanya asimetri informasi tidak menjamin terjadinya perilaku yang tidak etis. Hasil penelitian ini didukung oleh hasil 
penelitian Yuli (2013) yang menemukan bahwa asimetri informasi tidak berpengaruh terhadap perilaku tidaketis.

Hipotesis keenam (6) yang menyatakan bahwa asimetri informasi berpengaruh positif terhadap kecenderungan kecurangan akuntansi secara empiris tidak terbukti. Hal ini berarti menunjukkan bahwa tidak ada pengaruh antara asimetri informasi terhadap kecenderungan kecurangan akuntansi. Tidak berpengaruhnya asimetri informasi terhadap kecenderungan kecurangan akuntansi ini membuktikan bahwa adanya asimetri informasi tidak menjamin terjadinya kecurangan akuntansi. Hasil penelitian ini didukung oleh hasil penelitian Rahmawati (2012) yang menemukan bahwa asimetri informasi tidak berpengaruh terhadap perilaku tidak etis.

Hipotesis ketujuh (7) yang menyatakan bahwa moralitas manajemen berpengaruh negatif terhadap perilaku tidak etis secara empiris terbukti didukung. Hasil penelitian ini menunjukkan bahwa semakin baik moral manajemen atau karyawan pada perusahaan perbankan tempat responden bekerja maka akan semakin rendah perilaku tidak etis karyawan akuntansi dan keuangan pada perusahaan perbankan tersebut. Hasil pada hipotesis 7 mendukung penelitian Wilopo (2006), Fauwzi (2009), dan Bellyanti dan Rasmini (2016) yang menemukan bahwa moralitas manajemen berpengaruh negatif terhadap perilaku tidak etis.

Hipotesis kedelapan (8) yang menyatakan bahwa moralitas manajemen berpengaruh negatif terhadap kecenderungan kecurangan akuntansi secara empiris terbukti didukung. Hasil penelitian ini menunjukkan bahwa semakin baik moral para manajemen atau karyawan pada perusahaan perbankan tempat responden bekerja maka akan semakin rendah kecenderungan melakukan kecurangan akuntansi pada perusahaan perbankan tersebut. Hasil pada hipotesis 8 mendukung penelitian Wilopo (2006), Fauwzi (2009), Randa dan Meliana (2009), dan Rahmawati (2012) yang menemukan bahwa moralitas manajemen berpengaruh negatif terhadap kecenderungan kecurangan akuntansi.

Hipotesis kesembilan (9) yang menyatakan bahwa perilaku tidak etis berpengaruh positif terhadap kecenderungan kecurangan akuntansi secara empiris terbukti didukung. Hasil penelitian ini juga menunjukkan bahwa semakin tidak etis perilaku para manajemen atau karyawan pada perusahaan perbankan tempat responden bekerja maka akan semakin tinggi kecenderungan melakukan kecurangan akuntansi pada perusahaan perbankan tersebut. Hasil pada hipotesis 9 mendukung penelitian Wilopo (2006), Thoyibatun (2009), dan Hadi dan Prasaja (2015) yang menemukan bahwa perilaku tidak etis berpengaruh positif terhadap kecenderungan kecurangan akuntansi.

\section{KESIMPULAN DAN SARAN \\ Kesimpulan}

Penelitian ini dilakukan untuk menguji pengaruh efektivitas pengendalian internal, kesesuaian kompensasi, asimteri informasi, dan moralitas manajemen terhadap perilaku tidak etis dan kecenderungan kecurangan akuntansi serta perilaku tidak 
etis terhadap kecenderungan kecurangan akuntansi pada perusahaan perbankan di kota Bengkulu. Responden penelitian ini adalah karyawan akuntansi dan keuangan pada perusahaan perbankan di kota Bengkulu. Berdasarkan pada hasil pembahasan maka dapat disimpulkan sebagai berikut: (1) Efektivitas pengendalian internal berpengaruh terhadap perilaku tidak etis dan kecenderungan kecurangan akuntansi. (2) Kesesuaian kompensasi berpengaruh terhadap perilaku tidak etis dan kecenderungan kecurangan akuntansi. (3) Asimetri informasi tidak berpengaruh terhadap perilaku tidak etis dan kecenderungan kecurangan akuntansi. (4) Moralitas manajemen berpengaruh terhadap perilaku tidak etis dan kecenderungan kecurangan akuntansi. (5) Perilaku tidak etis berpengaruh terhadap kecenderungan kecurangan akuntansi.

Penelitian ini masih memiliki beberapa keterbatasan. Adapun keterbatasan penelitian ini yaitu: dalam penelitian ini hipotesis kelima tidak membuktikan bahwa asimetri informasi berpengaruh terhadap perilaku tidak etis dan hipotesis keenam juga tidak membuktikan bahwa asimetri informasi berpengaruh terhadap kecenderungan kecurangan akuntansi, hal ini dikarenakan indikator kuesioner dalam penelitian ini mengadopsi dari penelitian sebelumnya, sehingga ada beberapa indikator pada variabel asimetri informasi yang sulit untuk dipahami oleh responden dan Pemilihan sampel penelitian ini yaitu perusahaan perbankan yang merupakan perusahaan yang menjaga kerahasiaan yang sangat ketat sehingga mejadikan pendistribusian kuesioner tidak maksimal karena terdapat beberapa perbankan yang tidak bersedia mengisi kuesioner.

\section{Saran}

Berdasarkan pertimbangan masih adanya keterbatasan dalam penelitian ini, maka untuk penelitian selanjutnya dapat mempertimbangkan saran-saran berikut: bagi penelitian mendatang variabel yang tidak berpengaruh bisa tidak diuji atau diuji kembali, tetapi penelitian selanjutnya perlu mengevaluasi indikator yang ditanyakan pada kuesioner agar responden lebih mudah memahami isi dari pernyataan pada kuesioner yang peneliti berikan dan agi penelitian mendatang diharapkan untuk memperbanyak jumlah sampel dengan memperluas jumlah perusahaan yang dijadikan objek penelitian agarhasil penelitiannya lebih variatif.

\section{DAFTAR PUSTAKA}

Abdillah, Willy dan Jogiyanto. 2015. Partial Least Square (PLS)-Alternatif Structural Equation Modeling (SEM) dalam Penelitian Bisnis. Yogyakarta: CV. Andi Offset.

Bank Indonesia. 2003. Lampiran Surat Edaran Nomor 5/22/DPNP Pedoman Standar Sistem pengendalian Intern bagi Bank Umum yang dikeluarkan BI tanggal 29 September 2003.

Bellyanti, Luh Anggi dan Rasmini, Ni Ketut. 2016. Pengaruh Keefektifan Pengendalian Intern, Reward dan Moralitas Individu pada Perilaku Tidak 
Etis Karyawan (Studi CV. Sinar Dian). E-Jurnal Akuntansi Universitas Udayana, 14 (3), 1670-1698.

Chin,W.W. 1998. The Partial Least Squares Approach to Structural Equation Modeling. In G. A. Marcoulides(Ed.). Modern Methods for Business Research (295-336). Mahwah, New Jersey, London: Lawrence Eribaum Associates.

Cooper, Donald R., and Schindler, Pamela S. 2012. Business Research Methods, 12th ed.New York: McGraw-Hill.

Fauwzi, Mohammad Glifandi Hari, 2011. Analisis Pengaruh Keefektifan Pengendalian Internal, Persepsi Kesesuaian Kompensasi, Moralitas Manajemen Terhadap Perilaku Tidak Etis dan Kecenderungan Kecurangan Akuntansi. Jurnal Akuntansi Universitas Diponegoro.

Fornell, C. and Larcker, D.F. 1981. Evaluating Structural Equation Models with Unobservable Variables and Measurement Error. Journal of Marketing Research. 18 (1), 39-50.

Ghozali, Imam. 2014. Structurl Equation Modeling Metode Alternatif dengan Partial Least Square. Edisi 4. Semarang: Badan Penerbit Universitas Diponegoro.

Griffin, Ricky dan Ronald J. Ebert, 2006. Bisnis. Edisi Kedelapan. Penerbit Erlangga, Jakarta

Hadi, Syamsul dan Prasaja, Melati Puspitasari Dewi. 2015. Pengaruh Ketaatan Diri Dan Organisasi terhadap Perilaku Tidak Etis dan Kecurangan Akuntansi. Jurnal Bisnis dan Ekonomi, Volume 13, No. 2

Hasibuan, Malayu SP, 2009. Manajemen Sumber Daya Manusia, (Ed Revisi), Jakarta: PT Bumi Aksara.

Institut Akuntan Publik Indonesia, 2011, Standar Profesional Akuntan Publik, Jakarta: Salemba Empat.

Jensen, and W. H. Meckling, 1976. "Theory of the firm: Managerial behavior, agency costs and ownership structure." Journal of Financial Economics, vol. 3

Lambert, M. J, Hansen N.B, and Finch, A.E. 2001. Patient-Focused Research: Using Patient Data to Enhance Treatment Effect. Journal of Consulting and Clinical Psychology. 69 (2), 159-172.

Luthans, Freed. 2005. Perilaku Organisasi. Diterjemahkan oleh Vivin Andika Yuwono dkk.Edisi Pertama, Penerbit Andi, Yogyakarta. 
Meliany, Lia \& Hernawati, Erna. 2013. Pengaruh Keefektifan Pengendalian Internal dan Kesesuaian Kompensasi Terhadap Kecenderungan Kecurangan Akuntansi. Journal \& Proceeding Universitas Jenderal Soedirman, Vol III, No.1. Hal.1-10.

Nasution, Marihot dan Doddy Setiawan. 2007. Pengaruh Corporate Governance Terhadap Manajemen Laba di Industri Perbankan Indonesia. Simposium Nasional Akuntansi X.

Nicholson, W., 1997. Intermediate Microeconomics and Its Application, $11^{\text {th }}$ ed. Orlando: The Dryden Press.

Prasetyo, A. H. 2009. Tiga Dosa Besar Bank Century. (http://www.bpk.go.id, diakses 4 Oktober 2016).

Rahmawati, Ardiana Peni dan Soetik, Idjang. 2012. Analisis Pengaruh Faktor Internal dan Moralitas Manajemen Terhadap Kecenderungan Kecurangan Akuntansi. Jurnal Akuntansi Universitas Diponegoro.

Rahmawati, Jacob S dan Nurul Q. 2007. Pengaruh Asimetri Informasi Terhadap Praktik Manajemen Laba Pada Perusahaan Perbankan Publik yang Terdaftar di Bursa Efek Jakarta. Simposium Akuntansi Nasional IX, Padang, hal 5-8.

Randa, F., dan Meliana, 2009, Pengaruh Keefektifan Pengendalian Internal, Kesesuaian Kompensasi, Asimetri Informasi, Ketaatan Aturan Akuntansi, dan Moralitas Manajemen Terhadap Kecenderungan Kecurangan Akuntansi, Jurnal Sistem Informasi Manajemen dan Akuntansi, Vol. 7, No. 2.

Sarwono, Jonathan. 2007. Analisis Jalur Untuk Riset Bisnis: Aplikasi Riset Pemasaran, Keuangan, MSDM dan Kewirausahaan. Yogyakarta: Penerbit Andi.

Scott, W. R., 2003. Financial Accounting Theory $3^{\text {rd }}$ edition. Toronto: Prentice Hall. Sekaran, Uma. 2006. Metodologi Penelitian untuk Bisnis Buku 1 dan 2 Edisi Pertama. Jakarta: Salemba Empat.

Sugiyono. 2009. Metode Penelitian Kuantitatif, Kualitatif dan R\&D. Bandung: Alfabeta. Sujarweni, V.W. 2014. Metodologi Penelitian.Yogyakarta: PT.Pustaka Baru.

Sumantyo, R., 2003, Kasus Bank Lippo dan Degradasi Kepercayaan Publik, (http://www.suaramerdeka.com/harian/0302/24/eko1.htm, diakses 04 Oktober 2016). 
Thoyibatun, Siti. 2009. Faktor-Faktor Yang Berpengaruh Terhadap Perilaku Tidak Etis dan Kecenderungan Kecurangan Akuntansi Serta Akibatnya Terhadap Kinerja Organisasi. Jurnal Ekonomi dan Keuangan. Vol. 16, No.2.

Waworuntu, Bob. 2003. Determinan Kepemimpinan. Makalah Sosial Humaniora, vol.7, no.2, Desember 2003.

Widyaningdyah A.U. (2001). “Analisis Faktor-Faktor Yang Berpengaruh Terhadap Earning Management Pada Perusahaan Go Public Di Indonesia”. Jurnal Akuntansi \& Keuangan, Vol. 3, No. 2

Wilopo. 2006. Analisis Faktor-Faktor yang Berpengaruh Terhadap Kecenderungan Akuntansi. Simposium Nasional Akuntansi XI. Padang. Hal 21-68 